\title{
SIMPSON-EDINBURGH LOW-PRESSURE AIR BED: AN EARLY CLINICAL EVALUATION
}

By Elizabeth McClemont, M.B., Ch.B., D.C.H., D. C. Simpson, M.B.E., B.Sc., Ph.D., F.R.S.E., K. J. McCubBin, B.Sc., M.Sc., T. D. Dick, M.I.Mech.E., M.I.Prod.E., C.Eng., A. C. Buchan, F.D.S., F.R.C.S.E. and P. HARRIS, F.R.C.S.E., F.R.C.P.E., F.R.S.E.

Spinal Paralysis Unit, Edenhall Hospital, Musselburgh, Scotland; and Department of Bio-Engineering, Princess Margaret Rose Orthopaedic Hospital, Edinburgh, Scotland

Abstract. A simple, inexpensive low-pressure air bed has been developed for use in situations where decubitus ulcers may arise. This bed is currently being evaluated in patients with spinal injuries, both in the hospital situation and in the home. Early experience is highly encouraging as regular turning of the patient can be safely omitted. We feel that widespread use of this bed could greatly decrease the incidence of pressure sores.

Key words: Pressure sores; Special beds.

PRESSURE sores have been estimated to cost the National Health Service in Britain £, I00 000000 a year (Scales, I977). In June I976, a study group from Strathclyde University, in conjunction with the Greater Glasgow Health Board, conducted a I-day census in the Greater Glasgow Health Board area to obtain definitive information on the number of patients suffering from pressure sores (Jordan \& Clark, I977). The results were that 946 (88 per cent of 10750 patients studied) had pressure sores involving a breakage of the skin and 200 of the 946 were suffering from severe pressure sores.

All pressure sores are avoidable but to keep the at-risk patient free from this complication demands a high degree of skill and education, both in the hospital and in the community. It is bad practice to treat a decubitus ulcer without putting at least as much effort into improving the situation which led to its occurrence. Too often these causes seem irremediable, however; such as shortage of skilled staff, failing health of the patient and ageing or exhausted relatives. A simple support surface is needed which will remain safe and keep the patient free from skin breakdown despite deterioration of other circumstances.

\section{Special Beds}

Whilst recognising that there is no replacement for continuous and painstaking scrutiny of all pressure areas, several beds (Redfern et al., I973, Scales et al., 1974) have now been developed with the aim of reducing the nursing load on those caring for the severely disabled at risk to pressure sores. These beds can cost thousands of pounds, are often complicated to operate, and unwieldy to manage. Water beds, mud beds (Reswick et al., 1972) and sand beds (Stewart, 1970) all work on the principal of increasing the area over which pressure is exerted on the body, that is, using as much of the body's skin area as possible for support surface (Fig. I). 

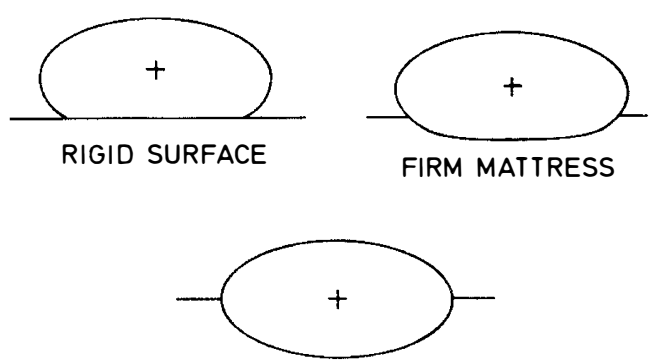

OPTIMUM SUPPORT SURFACE

eg 1 Mud Bed

2 Sand Bed

3 Low Loss Air Bed

4 Simpson-Edinburgh

Low Pressure Air Bed

FIG. I

Ripple mattresses (Gardner et al., 1954) and turning beds (Guttmann, 1965) alternate the areas of skin which have pressure exerted on them. Pressures on the support areas may be higher than with a conventional bed, but this is relieved before damage is done to the skin.

\section{The Low-Pressure Air Bed}

Two years ago, Professor David C. Simpson, Professor of Bio-Engineering at Edinburgh University, and $\mathrm{Mr} \mathrm{K}$. J. McCubbin started a project to develop a simple support surface which used readily available components (McCubbin and Simpson, 1977). The basic approach by the Unit was to design a bed in which the patient was supported by low-pressure air but which would act as if it was infinitely thick. By this it was meant that changes in the patient's posture or surface area of the patient in contact with the bed, which would result in a correspondingly different volume of air contained in the bed, should not affect the pressure.

Two standard, and readily available, camping air mattresses of the box-edge type are placed one above the other on a wooden base (Fig. 2). Two are required for the average patient to prevent 'bottoming' when they run at low pressure. For a patient who weighs in excess of about 90 kilos, a third would be necessary, but we have not as yet had occasion to require this. The two air mattresses are connected together by tubing which in turn is connected to a standard aquarium aeration pump. A further length of tubing is connected by means of a ' $T$ ' piece to the air line and the end of this tubing is immersed to a given depth in a column of water (Fig. 3). Within about 15 or $20 \mathrm{~min}$ after switching on the pump, both mattresses become fully inflated and the pressure inside them is regulated by the depth to which the side tube is immersed in the column of liquid. If a person is now placed on the mattress the consequent rise in pressure will drive air out of the system by bubbling out from the end of the tube until the pressure is once more at the pre-set level. Any further change in posture will result either in more excess air being 


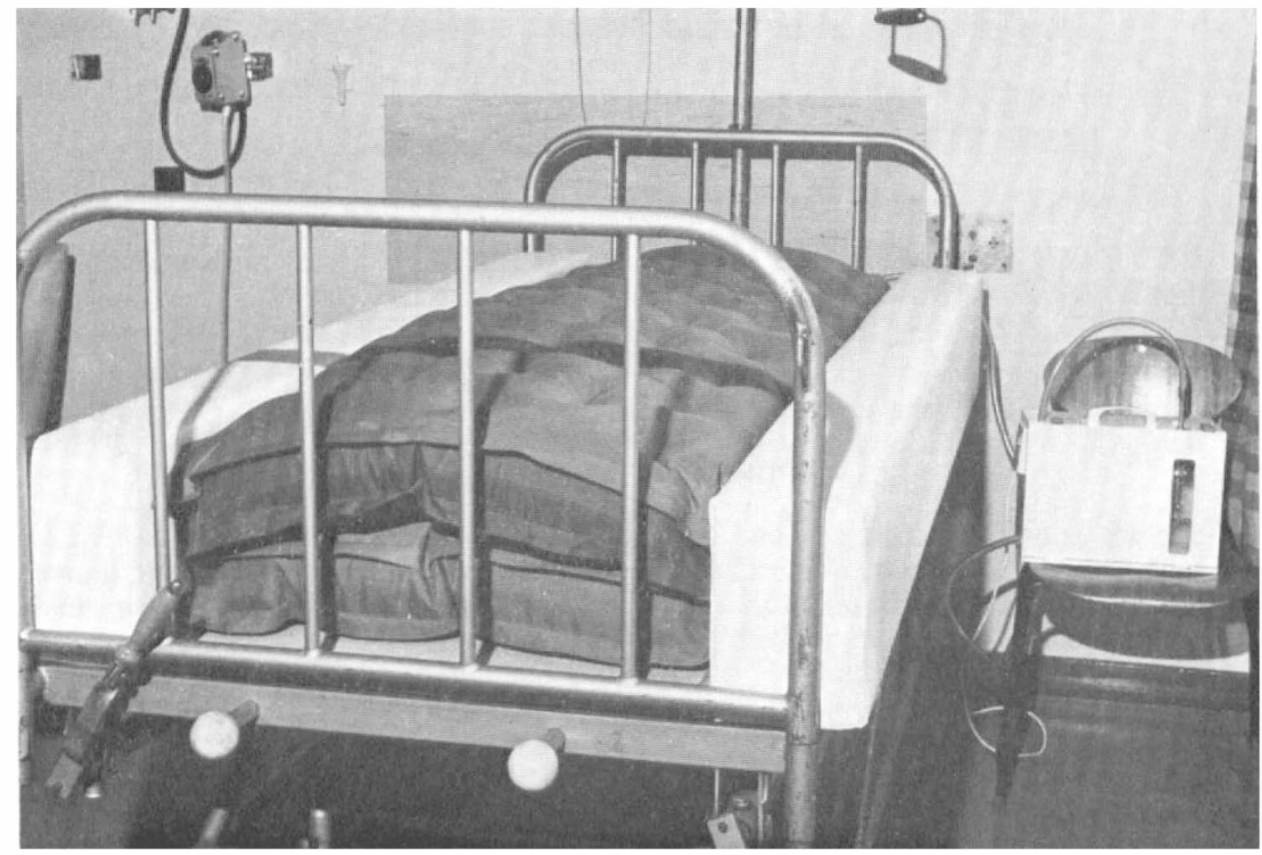

FIG. 2

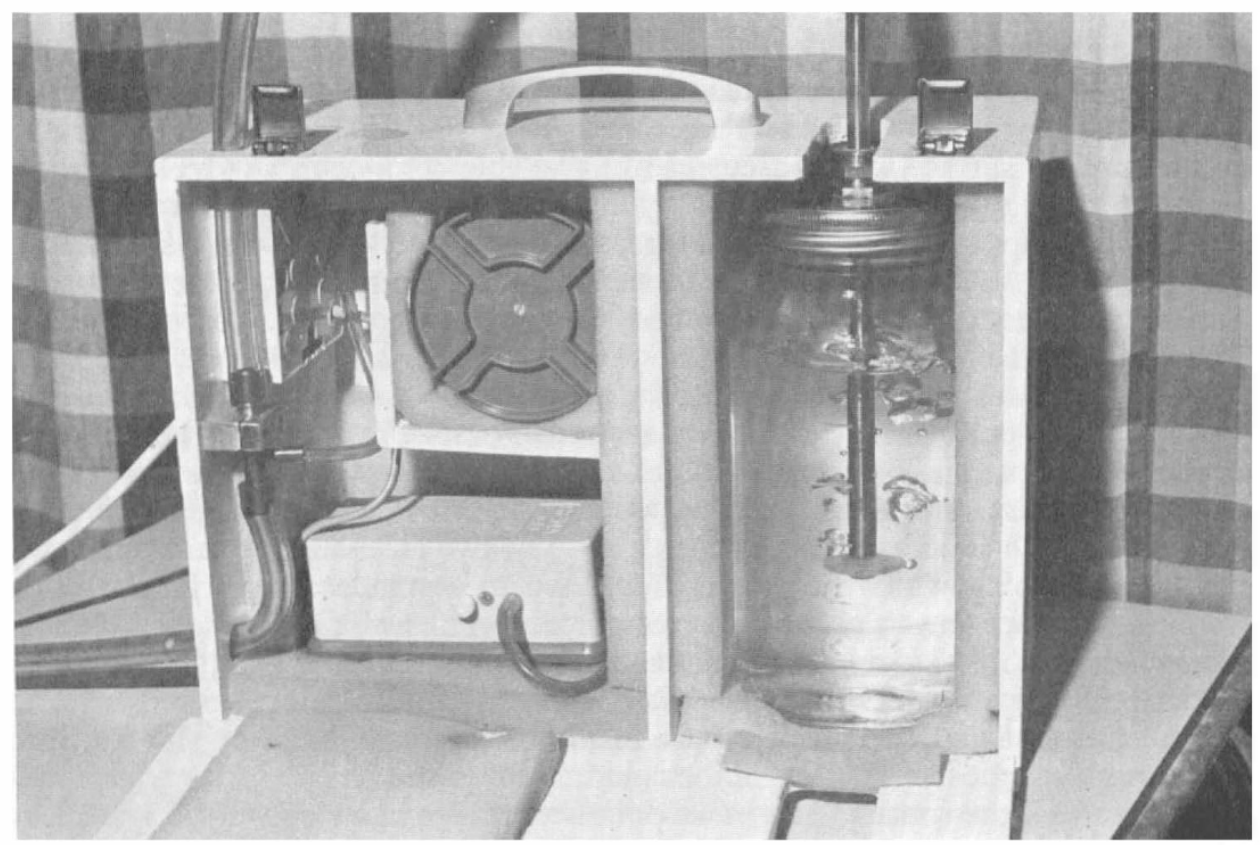

FIG. 3 
bubbled out, or else a pause in the discharge from the tube until the pressure has built up once more to the required pressure. In the steady-state condition the air from the pump passes directly out by bubbling from the tube and the pump then acts in the way it is designed to do in the aquarium.

The cost of the two mattresses plus the pump comes to about $£ 25$ and the baseboard, tubing, connectors, etc. could bring the cost to $£ 50-60$. A commercial firm in Scotland (Robert Kellie \& Son Limited) is now manufacturing the bed for $£ \mathrm{I} 60$, and some patients' families have built beds successfully from a 'Do-ityourself' manual.

\section{Clinical Use}

Four beds have been in constant use in the Spinal Paralysis Unit, Edenhall Hospital, since January I977. Our aim has been not to test the beds with as large a number of patients as possible, but to use a bed continually with each patient so that any faults or problems might arise over a period of time.

Our first experience of the bed was when A. M. (Table I) was admitted I2 months ago with a small sacral pressure ulcer. He was a severely emaciated man due to long-standing paraplegia and kyphoscoliosis, and had frequent admissions to the Spinal Unit with extensive pressure sores in the past. An early prototype of the low-pressure air bed was supplied for his use in his residential hospital in March 1975. Once his sacral sore, caused by wheelchair problems, was sound again, we obtained his air bed, put him on it and with some apprehension left him unturned for $\mathrm{I} 2$ hours. His skin remained intact and has continued to do so with constant use of the bed since that time.

We have concentrated our use of the air bed on patients with a high neurological level who would require frequent turning by attendants, and a few paraplegic patients with particular skin problems. After the initial few nights when checks of the skin are made at regular intervals during the routine turn times, the patient is left safely undisturbed, the only check being for bottoming on the support base at least twice nightly.

Patients on the air bed, confined to bed for various reasons, can be safely left undisturbed for 24 hours, the only lift being to change bed linen or reposition the patient who complains of discomfort. Two patients have been placed on the bed to hasten the taking of extensive skin grafts, previously disturbed by spasticity or friction caused by routine lifting and turning. One of these (W. S., Table I) remained supine for 9 weeks with only a single daily lift.

Eight beds are currently in use in the home situation (see ${ }^{\star}$ Table I). Following the instructions from a simple manual, some of these have been put together by relatives or friends with a modicum of technical expertise, all the necessary parts being easily available commercially. Few of these beds have been checked by the authors of this paper yet all are functioning satisfactorily, their occupiers are sleeping through the night unturned, and their skin remains sound. Some of these patients have been turned regularly for many years at home by relatives; other patients, with more recent spinal injury, have been discharged home more rapidly from the Unit as the relatives feel they can cope that much more readily with the freedom from frequent night attention. One tetraplegic university student has been able to return to his university hostel and complete his studies without the need for a night attendant to be found to turn him, and 2 weeks after obtaining an air bed, the parents of a highly disabled teenage girl requested that she be discharged home on a permanent basis. 


\section{TABLE I}

Patients on Simpson-Edinburgh low-pressure air bed

\begin{tabular}{|c|c|c|c|c|c|}
\hline Patient & Diagnosis & $\begin{array}{l}\text { Level } \\
\text { of } \\
\text { lesion }\end{array}$ & $\begin{array}{l}\text { Complete } \\
\text { or } \\
\text { incomplete }\end{array}$ & $\begin{array}{l}\text { Onset } \\
\text { of } \\
\text { injury }\end{array}$ & $\begin{array}{l}\text { Period } \\
\text { of } \\
\text { bed use }\end{array}$ \\
\hline A. M.ネ & Cord compression & $\mathrm{T} 8$ & Complete & I96I & 28 months \\
\hline G. A.* & Traumatic injury & C6 & Incomplete & 1976 & 6 months \\
\hline A. E.* & Transverse myelitis & $\mathrm{C}_{4}$ & Complete & I975 & 6 months \\
\hline H. D. & Traumatic injury & C6 & Incomplete & I97I & 7 weeks \\
\hline W. S. & Traumatic injury & Tio & Complete & I968 & I4 weeks \\
\hline W. D.` & Traumatic injury & $\mathrm{C}_{4}$ & Complete & I976 & 8 weeks \\
\hline J. R. & Traumatic injury & $\mathrm{C}_{5}$ & Complete & 1975 & 5 weeks \\
\hline F. L.* & Traumatic injury & C6́ & Complete & 1976 & 4 months \\
\hline R. S. & Traumatic injury. & $\mathrm{C}_{5}$ & Incomplete & 1976 & 3 months \\
\hline G. L. & Encephalo-myelitis & $\mathrm{C}_{7}$ & Incomplete & I968 & 4 days \\
\hline L. F. & Traumatic injury & C5 & Complete & I977 & 5 weeks \\
\hline G. M. & $\mathrm{A}-\mathrm{V}$ malformation & $\mathrm{T} 8$ & Complete & 1962 & 3 weeks \\
\hline R. M. & Cervical ependymoma & $\mathrm{C}_{7}$ & Incomplete & I97I & 2 weeks \\
\hline A. S. & Traumatic injury & $\mathrm{L} 2$ & Incomplete & I977 & 3 weeks \\
\hline A. B.* & Traumatic injury & C5 & Complete & I973 & 4 weeks \\
\hline J. S.` & Traumatic injury & $\mathrm{C}_{7}$ & Complete & 1976 & 5 months \\
\hline W. McI* & Traumatic injury & $\mathrm{C}_{7}$ & Complete & 1972 & 9 months \\
\hline
\end{tabular}

\section{Comments}

No patient has suffered skin breakdown whilst on the Simpson-Edinburgh Low-Pressure Air Bed. Erythema has been detected over pressure points in a few individuals but this can generally be prevented by adjusting the depth of pressure in the tube. One patient developed erythema and an area of induration due to undetected bottoming during his first night on the bed, stressing the importance of assessing the correct pressure setting for each individual patient. Another patient with a small area of redness also due to undetected bottoming, would probably benefit from a third mattress being a man of large proportions. Some patients express an ill-defined dislike of the support surface on their first night but, provided they are encouraged to persist with the bed, the advantages of a full night's sleep and not being disturbed for turns brings loud protests when they have to give up the bed for any other reason.

Tetraplegic patients with respiratory complications cannot be treated easily on this bed by the physiotherapist, and the bed is therefore unlikely to be suitable for patients with serious respiratory problems. We have not yet ascertained whether it is suitable for the early traumatic lesion who in any case requires frequent turning to prevent renal stagnation. Recognising the magnitude of the pressuresore problem in other fields of medicine besides spinal injuries, the Scottish Home and Health Department is currently carrying out a trial of the SimpsonEdinburgh Low-Pressure Air Bed in other units in the Edinburgh region with a wide variety of clinical disorders. Beds are in use in geriatrics, surgical neurology, orthopaedics and other high-risk situations. Full evaluation of results is awaited but we see no reason to anticipate results different from our own. 
Despite a limited trial period, we feel that the Simpson-Edinburgh LowPressure Air Bed has an important role to play in the management of the patient at risk from pressure sores, particularly in later stages of hospitalisation and in the home. Apart from our belief in its efficacy, this bed has the added advantages of low cost and simplicity of use, which would greatly increase its application and availability in many situations.

\section{SUMMARY}

The Simpson-Edinburgh low-pressure air bed, although still under evaluation, has so far proved highly sucessful in the long-term management of spinal injuries patients and other patients at risk from pressure sores. The patients using the bed, both in the home and the community, can lie safely without being turned and, providing the bed is used correctly, no patient has suffered any signs of skin breakdown. Our experiences so far have encouraged us to highly recommend this bed to patients who would otherwise require frequent turning and we believe that its widespread clinical use could greatly decrease the incidence of pressure sores.

\section{RÉSUMÉ}

On vient de développer une nouvelle espèce, très peu coûteuse, de lit pneumatique à pression minimum, qui peut servir dans les occasions où les lésions ou ulcères de décubitus pourraient se produire. On est en train d'évaluer l'utilité de ce lit pour les patients aux lésions spinales, soit à l'hôpital, soit comme traitement domiciliaire. Les premiers essais se sont déclarés for encourageants; ils tendent à démontrer que dès maintenant on peut en toute sécurité omettre de tourner régulièrement le patient, et que l'utilisation générale de ce lit réduirait de beaucoup l'incidence des lésions ou ulcères épidermales.

\section{ZUSAMMENFASSUNG}

Ein einfaches, sehr wenig kostbares, mit niedrigem Luftdruck aufblähbares Luftkissenbett ist hier neulich entwickelt worden, das in Fällen zu brauchen wäre, wo DecubitusGeschwüre $\mathrm{zu}$ fürchten sind. Solche Luftkissenbetten werden aktuell mit Patienten ausgewertet, die an Rückgratverletzungen leiden, und swar sowohl in der Klinik als auch in häuslichen Behandlungen. Die ersten Proben mit diesen Betten stellen sich als höchst ermutigend vor. Bei allgemeiner Anwendung davon kann man nunmehr das häufige Unwenden des Patienten ruhig ausbleiben lassen und trotzdem mit einer starken Abnahme der durch Druck veranlassten Hautverletzungen bzw-Geschwürbildung rechnen.

\section{REFERENCES}

GARDNER, W. J., ANDERSON, R. M. \& LYDEN, M. (I954). The alternating pressure pad: an aid to the proper handling of decubitus ulcers. Arch. Phys. Med., 35, 578.

Guttmann, L. (1965). A new turning-tilting bed. Paraplegia, 3, I93.

JORDAN, M. M. \& ClARK, M. O. (I977). The incidence of pressure sores on the patient community of the Greater Glasgow Health Board Area. Unpublished report.

Kellie, Robert \& Son, Ltd., Rutherford Road, Dryburgh Industrial Estate, Dundee, Scotland.

McCubBin, K. J. \& Simpson, D. C. (1977). A low-pressure air bed. F. Med. Engineering and Technology, $\mathbf{I}, 98-99$.

Redfern, S. J., Jeneid, P. A., Gillingham, M. E. \& LunN, H. F. (1973). Local pressures with ten types of patient-support system. Lancet, ii, 277-280.

Reswick, J. G., Simoes, N. F. \& Rogers, J. (1972). High-density flotation system for prevention and therapy of pressure sores-the M.U.D. bed. Presented at 25th Annual Conference of Engineering in Medicine and Biology.

SCales, J. T. (1977). Beware of the hospital bed. Nursing Mirror, March 3.

Scales, J. T., LunN, H. F., Jeneid, P. A., Gillingham, M. E. \& Redfern, S. J. (I974). The prevention and treatment of pressure sores using air-support systems. Paraplegia, I2, I I 8 .

Stewart, I. M. (1970). The sand bed. F. Bone and foint Surgery, 52-B, 799. 